\title{
Social media in surgery: evolving role in research communication and beyond
}

\author{
Rebecca Grossman $^{1}$ (D) - Olivia Sgarbura ${ }^{2,3} \cdot$ Julie Hallet $^{4,5} \cdot$ Kjetil Søreide $^{6,7}$ (D)
}

Received: 9 February 2021 / Accepted: 11 February 2021 / Published online: 28 February 2021

(C) The Author(s) 2021

\begin{abstract}
Purpose To present social media (SoMe) platforms for surgeons, how these are used, with what impact, and their roles for research communication.

Methods A narrative review based on a literature search regarding social media use, of studies and findings pertaining to surgical disciplines, and the authors' own experience.

Results Several social networking platforms for surgeons are presented to the reader. The more frequently used, i.e., Twitter, is presented with details of opportunities, specific fora for communication, presenting tips for effective use, and also some caveats to use. Details of how the surgical community evolved through the use of the hashtag \#SoMe4Surgery are presented. The impact on gender diversity in surgery through important hashtags (from \#ILookLikeASurgeon to \#MedBikini) is discussed. Practical tips on generating tweets and use of visual abstracts are presented, with influence on post-production distribution of journal articles through "tweetorials" and "tweetchats." Findings from seminal studies on SoMe and the impact on traditional metrics (regular citations) and alternative metrics (Altmetrics, including tweets, retweets, news outlet mentions) are presented. Some concerns on misuse and SoMe caveats are discussed.

Conclusion Over the last two decades, social media has had a huge impact on science dissemination, journal article discussions, and presentation of conference news. Immediate and real-time presentation of studies, articles, or presentations has flattened hierarchy for participation, debate, and engagement. Surgeons should learn how to use novel communication technology to advance the field and further professional and public interaction.
\end{abstract}

Keywords Social media $\cdot$ Research communication $\cdot$ Research dissemination $\cdot$ Internet $\cdot$ Influence $\cdot$ Gender diversity $\cdot$ Impact . Surgical research

Kjetil Søreide

ksoreide@mac.com

1 Oxford Centre for Diabetes, Endocrinology and Metabolism, University of Oxford, Oxford, UK

2 Department of Surgical Oncology, Cancer Institute of Montpellier, University of Montpellier, Montpellier, France

3 IRCM, Institut de Recherche en Cancérologie de Montpellier, INSERM U1194, Université de Montpellier, Institut régional du Cancer de Montpellier, F-34298 Montpellier, France

4 Department of Surgery, Odette Cancer Centre, Sunnybrook Health Sciences Centre, Toronto, Ontario, Canada

5 University of Toronto, Toronto, Ontario, Canada

6 Department of Gastrointestinal Surgery, Stavanger University Hospital, Stavanger, Norway

7 Department of Clinical Medicine, University of Bergen, Bergen, Norway

\section{Introduction}

In less than two decades since its inception, social media has had a dramatic impact on science dissemination, journal article discussions, conference news, and sharing of ideas and findings [1-4]. Social media relates to all internet-based applications used for social interaction in real time, be it for personal or professional use. It has changed several aspects of how, what, when, and with whom we communicate - this holds true not only in personal life, but more so in professional aspects and academia [4-6].

Medicine is no exception and surgeons have taken to the social media platforms with varying but increasing activity [7-9]. This method of research communication requires both attention, curiosity, critique, and scientific research. With several new opportunities for research communication, knowledge dissemination, education, and debates in real time, social media platforms are important tools for surgeons. However, in 
addition to opportunities and advantages, there are concerns, caveats, and pitfalls to this technology as well.

In this invited review, we present some of the aspects related to social media use for surgeons and how it influences modern research communication.

\section{How surgeons use social media platforms}

Since the invention of the printing press, methods for staying up to date with the latest medical evidence have evolved alongside the practice of evidence-based medicine itself. The speed of this evolution increased exponentially when the first scientific journals began to make their papers available online. The $B M J$ was the first major medical journal to launch a website, in 1995, and went fully online in 1998 [10]. From the mid-1990s, journals started offering the option to sign up for e-mail updates and RSS feeds (a method that allows a user to receive aggregated updates in a standardized format from multiple news sources).

Next came the blogs [11] (a term coined in 1997) and podcasts from the 2000s (the name was first used in 2004) [12]. Medical versions of these media are still incredibly popular. They allow journal editors and individual doctors to discuss, critique, and share important studies. Podcasts can be listened to at leisure, such as during commutes and exercise. Creating and maintaining them can be time-consuming. Hence, their use by surgical journals for communication with readers has been relatively inconsistent.

When Facebook (Facebook Inc., Menlo Park, CA, USA) was created in 2004, personalized news feeds became more appealing than RSS feeds [13]. Articles could be shared easily by friends and colleagues. More social networks then rapidly developed, and surgeons adopted them for socializing, networking, research, and practice promotion. Among colorectal surgeons in Australia and New Zealand, 59\% reported using social media (SoMe) for networking and $9 \%$ for research purposes [14]. A summary of these platform types are found in Table 1. Among the social media tools available, some are more popular among the surgical community than others. While only used by approximately one in five US adults [15], Twitter (Twitter, Inc., San Francisco, CA, USA) has become popular among healthcare professionals worldwide, for sharing information and online content; users can use it for both broadcasting and interacting [16]. The adoption of social media by the surgical community has been gradual. Twitter seems to be one of the platforms with largest uptake by surgeons $[3,8,17,18]$.

Table 1 Social media platforms and use among surgeons for research dissemination

\begin{tabular}{|c|c|c|c|}
\hline Type & Description & Examples & Examples of use \\
\hline Social networks & $\begin{array}{l}\text { Software that allows people to connect, either with } \\
\text { known contacts or strangers who share similar } \\
\text { interests via groups and hashtags, and share } \\
\text { multimedia and links }\end{array}$ & $\begin{array}{l}\text { Facebook, } \\
\text { Instagram }\end{array}$ & $\begin{array}{l}\text { Some journals have Facebook and Instagram } \\
\text { accounts to share papers and visual abstracts, and } \\
\text { some groups such as the International Bariatric } \\
\text { Club hold themed online chats }\end{array}$ \\
\hline $\begin{array}{l}\text { Business } \\
\text { networks }\end{array}$ & $\begin{array}{l}\text { As above, with a focus on sharing professional } \\
\text { information and resumes }\end{array}$ & LinkedIn & $\begin{array}{l}\text { Share professional updates and blog posts, } \\
\text { participate in group conversations }\end{array}$ \\
\hline $\begin{array}{l}\text { Science and } \\
\text { research } \\
\text { networks }\end{array}$ & $\begin{array}{l}\text { Allow researchers to log and share publications and } \\
\text { other academic work }\end{array}$ & $\begin{array}{l}\text { ResearchGate, } \\
\text { Mendeley }\end{array}$ & $\begin{array}{l}\text { Log and share papers, request access to papers that } \\
\text { are behind a paywall }\end{array}$ \\
\hline Blogging & $\begin{array}{l}\text { A way to publish articles online in various formats in a } \\
\text { user-controlled way }\end{array}$ & $\begin{array}{l}\text { WordPress, } \\
\text { Tumblr }\end{array}$ & $\begin{array}{l}\text { Editorialize and summarize work in plain language. } \\
\text { Useful for public engagement }\end{array}$ \\
\hline Microblogging & $\begin{array}{l}\text { Character-limited posts, able to share multimedia and } \\
\text { URL links }\end{array}$ & Twitter & $\begin{array}{l}\text { Used by large number of journals and researchers to } \\
\text { share research summaries, links to papers, and } \\
\text { teaching cases }\end{array}$ \\
\hline Video sharing & $\begin{array}{l}\text { Allow users to "vlog" and share videos to followers or } \\
\text { the general public }\end{array}$ & $\begin{array}{l}\text { YouTube, AIS } \\
\text { (Advances in } \\
\text { Surgery), } \\
\text { WebSurg }\end{array}$ & $\begin{array}{l}\text { Used for sharing educational videos, lectures, and } \\
\text { videos of surgical techniques }\end{array}$ \\
\hline Gaming networks & $\begin{array}{l}\text { Allow players to play together, stream games, and chat } \\
\text { online }\end{array}$ & Twitch & Potential for simulation training \\
\hline Wiki-based & Collaborative editing of an information source & $\begin{array}{l}\text { Wikipedia, } \\
\text { SAGES } \\
\text { Surgical Wiki }\end{array}$ & $\begin{array}{l}\text { Can contribute to evidence-based surgical } \\
\text { knowledge, citing scientific papers as sources }\end{array}$ \\
\hline $\begin{array}{l}\text { Group-messaging } \\
\text { service }\end{array}$ & $\begin{array}{l}\text { Allows users to send instant messages across different } \\
\text { platforms to contacts and channels }\end{array}$ & $\begin{array}{l}\text { WhatsApp, } \\
\text { Signal, } \\
\text { Telegram, } \\
\text { WeChat }\end{array}$ & Can share papers with contacts \\
\hline Discussion fora & $\begin{array}{l}\text { Website that allows social news aggregation, content } \\
\text { rating, and discussion }\end{array}$ & Discord, Reddit & Ability to chat online about new papers \\
\hline
\end{tabular}




\section{Social networks}

Facebook is one of the most used platforms; e.g., in the USA, it is used by over two-thirds of the adult population [15]. Despite this, it is infrequently used by individual surgeons for purely professional purposes, as it encourages users to share personal information such as family members and tagged pictures of private events that are not always appropriate for professional interactions. However, as it allows a "closed" membership, it is used by some societies to facilitate discussions and engagement [19]. This approach leverages members' existing social media accounts and familiarity with the platform to engage them in case discussion and webinars, thereby broadening participation compared to society-specific web platform that requires separate processes and login. It can also add a socializing and networking aspect to discussions that was previously achieved mostly at in-person conferences. Instagram (Facebook Inc., Menlo Park, CA, USA) is owned by Facebook and is used by a younger demographic. Due to it being primarily an imagesharing platform, it is popular within plastic and aesthetic surgery $[20,21]$. It is also used by private medical institutions to advertise medical activity and facilities [17].

\section{Blogs}

Surgical blogs have experienced a recent renaissance [22, 23]. Blogging is a good vehicle for topics not covered in traditional scientific literature and that require a more extensive coverage than the short format proposed on the other platforms. Surgical blogs may be targeted to a specific audience, such as the Association of Women Surgeons (AWS) blog [23]. This example generates high numbers of unique user views and provides unique content, such as topics including "graduate and postgraduate education" and "family life," among others. Blogs can also be used by scientific journals. BJS created a blog that allows the journal's editors and authors to post articles on themes that are not traditionally found in a printed journal (The Cutting Edge blog https://cuttingedgeblog.com). These posts stimulate debate and allow reflection in an alternative way. In addition, they allow the communication of the findings of surgical research in plain language, to make it available to the general public. This is an important method of countering widespread medical misinformation online. Surgical blogs can thus be used for knowledge dissemination and translation, as well as patient engagement in research. Research outputs can be shared with the surgical community, policy-makers, and patients in formats more accessible than scientific articles. Clinical trials and ongoing studies can be shared to improve centers' participation and patient recruitment [24]. Interactive features can also be used to obtain input and feedback through the design, conduct, and interpretation of research projects to foster patient and service user engagement that is key to impactful research [25].
Video sharing

YouTube (Google LLC, San Bruno, CA, USA) is the most popular form of social media in the USA, with three-quarters of adults using the platform [15]. It is particularly useful for sharing educational videos, recorded lectures, webinars, and instructional procedure videos. Research suggests there is broad uptake of these videos [26, 27]. Several surgical specialties have used this form of knowledge distribution for various procedures [28-31]; however a recurring concern is the validity and usefulness of the content posted [32-34]. There is no surgical content curator on YouTube. Hence, the inexperienced surgeon may be led astray into poorly crafted and potentially erroneous videos, which is a pitfall to the widespread dissemination available by these platforms. Compared with traditional journal articles in a professional surgical journal, social platform content is not vetted to a given standard with editorial input or external referees. Thus, bias (unconscious and conscious) and errors are rife. In a cross-sectional study of YouTube videos demonstrating laparoscopic fundoplication, only $39.4 \%$ were evaluated as "good"; goodrated videos correlated with longer duration [35]. Similarly, an analysis of YouTube videos presenting D2 lymphadenectomy for gastric cancer highlighted the high variability in the quality of the technique presented using validated scoring tools [36]. Higher quality videos have supplementary commentary [26]. Trainees may also evaluate the quality of a surgical video differently to senior surgeons [34] and should therefore be steered towards the higher quality videos by their instructors.

Formal curation is provided by other video platforms, such as WebSurg and the AIS (Advances in Surgery) Channel. As with other online streaming platforms, these tools gained more visibility during the Covid-19 pandemic, when in-person congresses were cancelled and partly replaced with virtual events [37]. It is unclear what the role of these formats will be once in-person conferences resume, but their persistence seems certain.

\section{How it started: \#SoMe4Surgery and related hashtags}

One of the ways to maximize the benefits of social media use is to employ hashtags, which are metadata tags that are usergenerated/"bottom-up" [38]. This allows users to engage in conversations that are related to a certain topic. Various surgical hashtags exist. \#SoMe4Surgery is both one of the most widespread and most surgeon-specific on Twitter [39] (Fig. 1). The hashtag was developed through several phases and described in detail elsewhere [39]. Briefly, an inception phase was initiated for a connection between participants: users were actively invited to participate. Second, a dissemination phase was launched to help the spread (contagion) and the material 
going viral. In this phase, several tweetchats were designed, scheduled, and run. Further, a third step was the adherence phase (feedback): Twitonomy and NodeXL summaries were regularly posted on Twitter to gauge and inform activity and response. Eventually, an impact phase in which outcome was the focused gain [1,39]. Created in August 2018, after 2 years and 4 months, the \#SoMe4Surgery network and the twitter handle (@me4_so) had reached over 5000 followers, with considerable interaction (Fig. 1). Currently, a long list of twitter handles related to surgeons' interest is available (Table 2).

\section{Social media and social change}

It is possible for content to be shared online in such a way that it spreads extremely rapidly, i.e., "going viral." Examples of hashtags that went viral in the "Twittersphere" (Twitter ecosystem) and have had a huge social influence on surgery include \#ILookLikeASurgeon, the \#NYerORCoverChallenge (Fig. 2), and \#HerTimeIsNow. These hashtags have celebrated diversity, raised awareness of discrimination and microaggression, and promoted the recognition of women surgeons [3]. Indeed, social media has addressed sexism in science in a wider perspective [40], stirring debate and encouraging progress towards gender equity and opportunities. As such, \#ILookLikeASurgeon has become a global phenomenon [41] with several specialties taking up the challenge [42].

Social media allows for wider inclusion. It is now easier for junior surgeons or underrepresented groups to create a voice for themselves and make their expertise and contributions known. This helps to make them more accessible for opportunities such as invitations for speaking engagements, whereas without social media, this would be contingent on contacts and networking at meetings, which is not possible nor intuitive for all. SoMe also allows more opportunities to amplify others, support, and promote one another. This has certainly been the case for women within the American Hepatobiliary Pancreatic Association (AHPBA) with the hashtag \#hpbheroines. While not all hashtags may go "viral," they may become impactful, even powerful, tools in certain communities. Indeed, speaker representation of women in the IHPBA conference held in Brisbane 2020 was altered after the Twitter community noted the lack of women invited speakers. Hence, social media may bring a "diversity bonus" by fostering teams that would not have existed otherwise - be it for conferences, webinars, or research collaborations.

However, there are still limitations. Social media does not entirely protect for disparities, and geographical disparities in particular have already been identified in the use of social platforms. Independently of their utility, some platforms are preferred by users based on their local popularity [15, 43, 44]. Although access to the global conversation in surgery on Twitter is free of charge, and experts are present and active, some countries still remain underrepresented, as it has already been shown at a more global level [45]. Potential reasons for geographical disparities range from poverty and lack of resources, preventing access to the internet, to political (in countries with restricted freedom of speech), linguistical, and cultural.

\section{Social media engagement in research-from idea to project}

It is possible for a research paper to be entirely conceived, constructed, contributed to, and disseminated via social media. The phenomenal advantage of this concept is the ability to collaborate with esteemed international colleagues with which it would otherwise be impossible to network. In addition, social media acts to "flatten the hierarchy," allowing junior researchers to approach legends of their specialties with their own ideas, in return stimulating their own interest in research (Table 3).

\section{Post-production}

Following publication, there are numerous methods of disseminating research to maximize impact. Some advice for promoting papers on Twitter are found in Table 4.

\section{Tweetorials}

Tweetorials, or tweet tutorials, are explanatory Twitter threads posted on an academic topic [60] (see example Fig. 3). They are often posted by the authors of papers to explain their findings in plain language and employ the use of images from the paper as well as animated GIFs to illustrate the topic. Because the paper is explained in short, 280-character snippets, they are effective tools to summarize the key points of a paper. The caveat is that if threads are too long, the audience may not read to the end (a reflection of the short attention span encouraged by the use of microblogging sites).

\section{Tweetchats}

A tweetchat is an open conversation on Twitter, usually based around the use of a hashtag, and often guided by one or two accounts that may post a series of questions designed to stimulate discussion [16]. They are employed by medical journals, researchers, and journal clubs to promote published papers and are highly effective in increasing the alternative metrics (Altmetrics) and reach of the paper, with impressions (number of times the hashtag has been viewed) sometimes in the millions. In one study [16], individual tweets from a journal tweetchat were extracted using Twitter analytics in addition 
Table 2 Social media handles for specific surgical interest groups evolved since 2017

\begin{tabular}{|c|c|c|c|}
\hline Name & Twitter handle & Purpose & Launched \\
\hline SoMe4Transplant & $@$ SoMeTransplant & $\begin{array}{l}\text { @ SoMeTransplant connecting all \#healthcare workers, \#students and \#patients } \\
\text { interested in \#Transplantation \#SoMe4Transplant }\end{array}$ & $\begin{array}{l}\text { September } \\
2017\end{array}$ \\
\hline SoMe4Surgery & @me4_so & $\begin{array}{l}\text { This is @ juliomayol working in the dark for the \#SoMe4Surgery network Surgical } \\
\text { Research Surgical Practice Social Behavior - Powered by BioCirugia }\end{array}$ & $\begin{array}{r}\text { August } \\
2018\end{array}$ \\
\hline UroSoMe & @so_uro & $\begin{array}{l}\text { We're an international group of urologists and trainees who are interested in the } \\
\text { utility of Social Media in Urology. Start by using the hashtag \#UroSoMe ! }\end{array}$ & $\begin{array}{r}\text { August } \\
2018\end{array}$ \\
\hline SoMe4Endocrine & @ SEndocrine & Connecting the endocrine community & $\begin{array}{r}\text { January } \\
2019\end{array}$ \\
\hline SoMe4MITherapy & @ me4_mi & $\begin{array}{l}\text { Devoted to share information and to connect all those people interested in all forms of } \\
\text { interventional therapy - Powered by Biocirugia }\end{array}$ & $\begin{array}{r}\text { January } \\
2019\end{array}$ \\
\hline SoMe4Precision & @PrecisionSo & $\begin{array}{l}\text { The \#SoMe4Precision community aims to identify and alleviate factors preventing } \\
\text { the widespread implementation of personalised medicine in healthcare }\end{array}$ & $\begin{array}{r}\text { January } \\
2019\end{array}$ \\
\hline @ SoMe4SurgeryPrehab & @ SoMe4SurgeryPr1 & $\begin{array}{l}\text { Interés por el bienestar de los pacientes. Luchando por implantar los cuidados } \\
\text { preoperatorios en las cirugías mayores }\end{array}$ & $\begin{array}{r}\text { January } \\
2019\end{array}$ \\
\hline SoMe4Peritoneum & $@$ SPeritoneum & $\begin{array}{l}\text { Peritoneal Surface Malignancies SoMe global community for all surgeons, } \\
\text { researchers and patients... peritoneal carcinomatosis, HIPEC, PIPAC }\end{array}$ & $\begin{array}{r}\text { January } \\
2019\end{array}$ \\
\hline SoMe4Bariatrics & @ BariatricsSo & Using \#SoMe to fight the global obesity epidemic -\#SoMe4Surgery & $\begin{array}{r}\text { January } \\
2019\end{array}$ \\
\hline SoMe4Trainees & @ SoTrainees & $\begin{array}{l}\text { Connecting surgical trainees from all over the world - led by @CarlosSaez_and } \\
\text { @ juliomayol }\end{array}$ & $\begin{array}{r}\text { January } \\
2019\end{array}$ \\
\hline SoMe4IBD & @ some4ibd & $\begin{array}{l}\text { \#SoMe4IBD connecting gastroenterologists, surgeons \& patients interested in IBD } \\
\text { Fueled by @LuisSanchezGlln \& @ GianlucaPellino under the auspices of } \\
\text { @juliomayol }\end{array}$ & $\begin{array}{c}\text { February } \\
2019\end{array}$ \\
\hline SoMe4retina & $@$ me4retina & $\begin{array}{l}\text { This is @ draPilarCalvo trying to help people see. Retina is our passion: clinic, } \\
\text { teaching and research \#some4retina }\end{array}$ & $\begin{array}{l}\text { February } \\
2019\end{array}$ \\
\hline SoMe4HPB & @hpb_so & HPB surgery in the twittsphere \#SoMe4HPB & $\begin{array}{l}\text { February } \\
2019\end{array}$ \\
\hline \#SoMe4Anesthesia & @ some4anesthesia & \#SoMe4Anesthesia & March 2019 \\
\hline Some4MDT & @ MdtSome4 & $\begin{array}{l}\text { Multidisciplinary Team approach for coordinated care, patient at the heart of all we } \\
\text { do! }\end{array}$ & May 2019 \\
\hline SoMe4Trauma & @ Me4Trauma & $\begin{array}{l}\text { \#SoMe4Trauma is a \#SoMe4Surgery initiative that aims to bring Trauma Surgery } \\
\text { into focus on social media. @me4_so @a160186 @ juliomayol Instagram: } \\
\text { some4trauma }\end{array}$ & July 2019 \\
\hline \#SoMe4PedSurg & $@$ Me4Ped & $\begin{array}{l}\text { A global initiative for all Surgical\&Paediatric Information on \#SocialMedia for } \\
\text { Pediatric Surgeons mainly Just share it \#SoMe4PedSurg-\#SoMe4Surgery } \\
\text { Movement- }\end{array}$ & July 2019 \\
\hline SoMe4endoscopy & @ SoMe4endoscopy & $\begin{array}{l}\text { \#SoMe4endoscopy connecting gastroenterologists and surgeons interested in } \\
\text { endoscopy. A \#SoMe4Surgery initiative. @ drfrancescopata @ stevenbollipo } \\
\text { @ RashidLui }\end{array}$ & July 2019 \\
\hline @SoMe4MV & @ some4mv & $\begin{array}{l}\text { Multi-professional profile focused on mechanical ventilation and respiratory diseases } \\
\text { in critical patient. Managed by @ ventilacionmeca and @ Nopanaden \#SoMe4MV }\end{array}$ & July 2019 \\
\hline SoMe4GynOnc & @GynMe4 & $\begin{array}{l}\text { Social media platform promoting the goal of curing Gynecologic Cancer; hosted by } \\
\text { @ GreggNelsonERAS }\end{array}$ & July 2019 \\
\hline SoMe4Breast & @ BreastMe4 & $\begin{array}{l}\text { We are \#GlobalSurgeons studying and fighting with our knowledge and Daily } \\
\text { practice to BREAST CANCER and other diseases related-_ @ martajimenez135 }\end{array}$ & July 2019 \\
\hline SoMe4SurgicalEducation & $\begin{array}{l}\text { This is an account for } \\
\text { surgical education }\end{array}$ & This is an account for surgical education & July 2019 \\
\hline SoMe4CT & @ SoMe4CT & $\begin{array}{l}\text { Social Media \#SoMe for the Cardiothoracic Surgery community \#SoMe4CT : An } \\
\text { attempt to unify everybody involved in the chest diseases. Powered by @jiseav }\end{array}$ & July 2019 \\
\hline SoMe4AmbSurg & @ AmbMe4 & $\begin{array}{l}\text { Global iniciative [sic] for people, students, nurses, doctors and all Team related } \\
\text { Ambulatory Surgery, \#SoMe4AmbSurg, patient safety, surgery, innovation, } \\
\text { research }\end{array}$ & July 2019 \\
\hline SoMe4SurgicalAI & $@ \mathrm{Me} 4 \mathrm{Ai}$ & $\begin{array}{l}\text { Part of \#SoMe4Surgery initiative. Platform for healthcare professionals an AI/data } \\
\text { scientists to meet, debate, collaborate. \#SoMe4SurgAI. Hosted by @ HansL16 }\end{array}$ & $\begin{array}{r}\text { August } \\
2019\end{array}$ \\
\hline TUGS & @T4UGIS & $\begin{array}{l}\text { The Upper Gastrointestinal Surgeons (TUGS) represents all of Upper } \\
\text { Gastrointestinal Surgery including its various subspecialties globally. \#TUGS }\end{array}$ & $\begin{array}{c}\text { October } \\
2020\end{array}$ \\
\hline
\end{tabular}




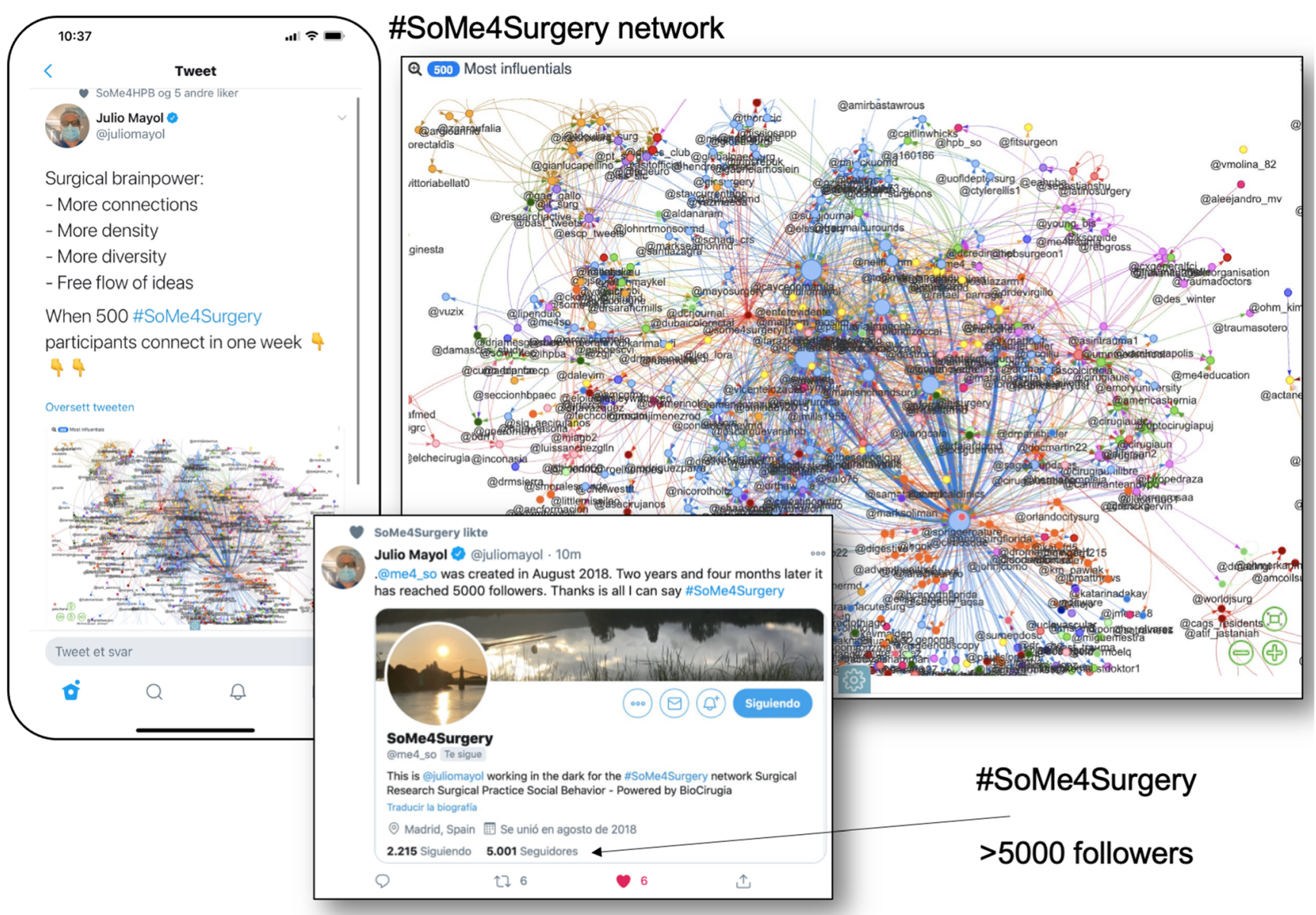

Fig. 1 The "SoMe4Surgery" network illustrated. Created in August 2018 by Professor Julio Mayol. After 2 years and 4 months, the \#Some4Surgery network and the Twitter handle (@me4_so) had reached over 5000 followers, with considerable interaction

to third-party applications NodeXL and Twitonomy, which showed that 37 Twitter accounts posted 248 tweets or replies, with only $58.5 \%$ identified using the hashtag of the tweetchat. It is therefore possible for the conversation to quickly become disorganized and difficult to follow, particularly if participants forget to include the hashtag. Third-party applications may also overestimate the reach of hashtags.

\section{Condensed communication-from $\mathbf{2 8 0}$ characters to visual abstracts}

The traditional form of condensed presentation is through the scientific abstract - either as a meeting abstract or as a condensed part of a journal article (Fig. 4). The structured part of an article usually consists of about 250 words following the IMRaD (introduction, methods, results, and discussion) structure [61].

The "visual abstract" has not replaced but added visual value to the traditional scientific abstract [62-64]. Most surgical journals now post visual abstracts of many of their published studies (Fig. 5). Indeed, some journals, like the Journal of American College of Surgeons (JACS) and JAMA Surgery, require authors to provide a visual abstract of their work at the time of article submission or revision. Suggested information to include in a visual abstract are found in Table 5 [65].

\section{Specialized feeds for disseminating research}

Social media platforms such as Twitter are immensely useful for keeping up to date with the latest research. However, feeds can often be cluttered by a mixture of useful links to journals, distracting viral videos, and photographs of pets. A relatively new trend is of Twitter accounts that act to filter out the noise (Table 6). These are usually run by volunteers with a passion for academic medicine, who act to curate and filter the papers by specialty, as opposed to the personal accounts of doctors and scientists, who may post mainly their own work. Some are run by bots. Following the creation of the \#SoMe4Surgery hashtag and @me4 so (SoMe4Surgery) Twitter account [39], numerous subspecialty surgical accounts were created to curate content, with some examples shown in Table 2. 
a \#NYerORCoverChallenge

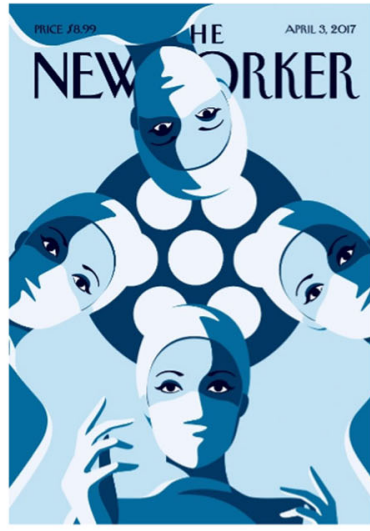

C

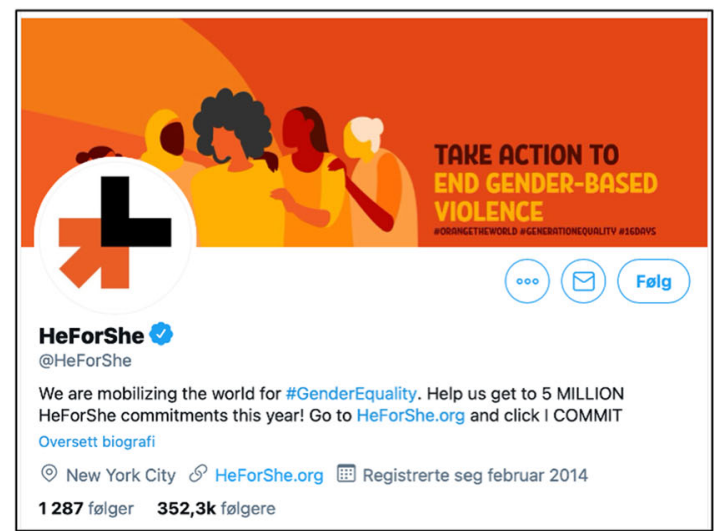

b

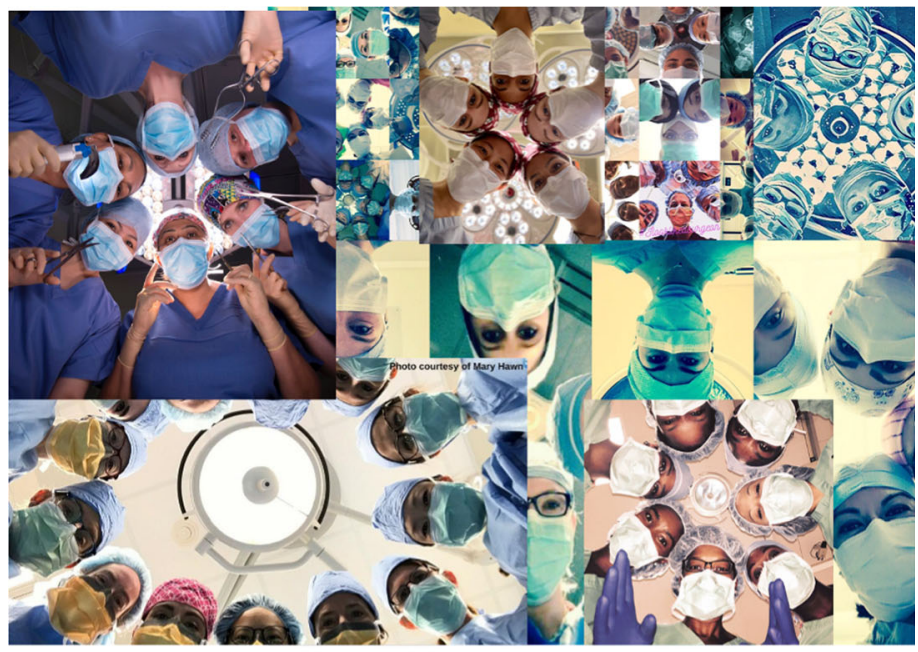

d

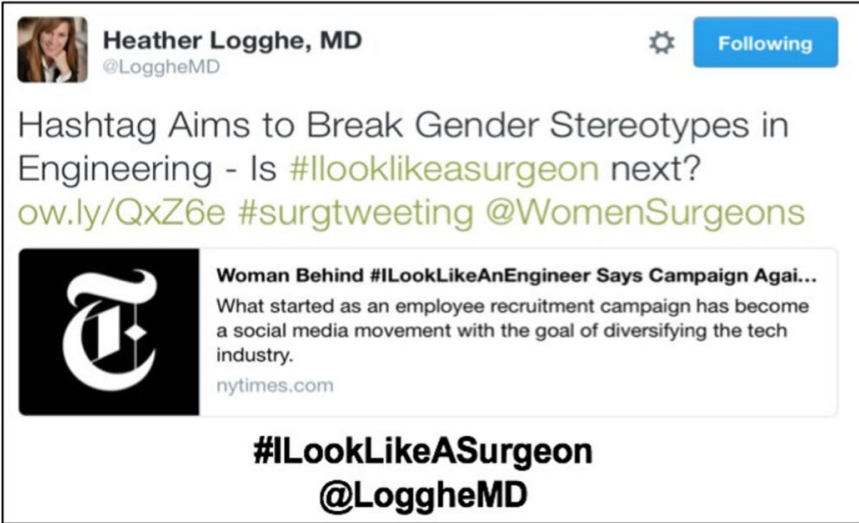

thus giving a face to the thousands of women surgeons in current surgical practice. (C) The HeForShe Twitter handle mobilizing for gender equity. (D) The initial tweet by Heather Logghe starting the \#ILookLikeASurgeon hashtag that eventually went viral

Furthermore, social media communication of research results can reach broader audiences that traditionally have difficult access to scientific communication owing to journal paywalls and hermetic language. For instance, patient advocacy organizations and policy-makers can be kept appraised of new research findings in real time. This contributes to relaying and democratizing information for patients as well as impact on care processes and policies.

\section{New metrics of impact: Altmetrics and more}

For what it is worth and with all its flaws, scientific papers and researchers have traditionally been evaluated by the impact of their work based on where they publish (rank of journal and its impact factor), how many times their work is cited (for any given paper and time period), and their accumulating $H$-index (the sum of citations accrued over years of active research) [79, 80]. With the emergence of social media platforms, new bibliometric profiles measuring impact and exposure of scientific research online another, to show highlights of debates and opinions [75-78]. 
Table 3 Social media involvement leading to new research ideas

\begin{tabular}{|c|c|c|}
\hline Phase/stage & Description & Examples \\
\hline Idea & $\begin{array}{l}\text { Ideas can arise from online dialogues, tweetchats, } \\
\text { commentaries, or posted articles }\end{array}$ & $\begin{array}{l}\text { The idea for the paper "The Way to Man's Heart Is through the Stomach" } \\
\text { [46], and the collaboration between colleagues at different institutions, } \\
\text { arose from a Twitter conversation. Twitter accounts involved in the original } \\
\text { conversation were mentioned in the acknowledgements. }\end{array}$ \\
\hline $\begin{array}{l}\text { Working } \\
\text { groups }\end{array}$ & $\begin{array}{l}\text { Affinities, similar position, spontaneous organization } \\
\text { around an idea in a tweet chat }\end{array}$ & $\begin{array}{l}\text { Surgical ergonomics working group spearheaded by @ GeetaLalMD } \\
\text { following discussions on this topic on live tweets from surgical conferences }\end{array}$ \\
\hline Collaborations & Collaborative studies either prospective or retrospective & $\begin{array}{l}\text { Prospective: LiverGroup.org; PancreasGroup.org } \\
\text { Surveys } \\
\text { Retrospective } \\
\text { COVIDSurg collaborative }[47-51]\end{array}$ \\
\hline Recruitment & $\begin{array}{l}\text { Post adverts to recruit sites and patients to studies, and } \\
\text { post updates on how recruitment is progressing [52] }\end{array}$ & Sunflower study \\
\hline Application & $\begin{array}{l}\text { Tweet surveys have known a remarkable popularity } \\
\text { during the Covid-19 pandemic }\end{array}$ & Several Covid-19 surveys $[53,54]$ \\
\hline $\begin{array}{l}\text { Journal } \\
\text { selection }\end{array}$ & Different policies on Twitter & Ex. $B J S$ - since 2014 \\
\hline Dissemination & Conference live-tweets, online congresses & Surgical conferences with monitored Twitter activity [55-59] \\
\hline $\begin{array}{l}\text { Innovative } \\
\text { formats }\end{array}$ & $\begin{array}{l}\text { Specific interactions around ideas or research limited to } \\
\text { the use of a SoMe platform }\end{array}$ & \#HPBdailyRead, shared HPB-specific info on a hashtag for followers \\
\hline
\end{tabular}

have been introduced as an Altmetrics (Fig. 6) to traditional bibliometric outcomes. Indeed, the influence of social media activity has become an interest for academics for several reasons [46], not only to gauge the actual tweets and retweets, but also whether this activity may turn into higher citation rates and wider impact of the research [47-49]. Currently, very few studies exist in general surgery, but one study found a positive correlation between Altmetric scores and citations [74]. Notably, Altmetric scores should not necessarily be used as a surrogate marker for evaluating research performance, impact, or exposure. It is possible, however, that as the use of social media for distributing and sharing scientific research continues to expand, that exposure on such platforms could impact future interest or studies.

Table 4 Advice for promoting papers on Twitter

Annotate: give different information than just the title, explain the study Remember to post the URL to the study and ensure no broken links

Ensure abstract is available to read

Use medical hashtags

Use images, emoticons, GIFs, or visual abstracts

Tag the research team (can be tagged on a posted photo if characters limited)

Tag key Twitter users that may be interested in the study: surgeons, patients organizations, surgical associations, policy-makers (locally or internationally)

Ask questions about the implications of the work-open-ended or use Twitter polls

Like, thank, and reply if other users RT the study or comment on the study

Follow Altmetric reports if available - will show tweets and social media posts that one may have missed otherwise
One study found that Twitter activity was associated with higher research citation index among academic thoracic surgeons [50]. In a unique randomized study conducted among a network of cardiothoracic surgical journals [51] called the Thoracic Surgery Social Media Network [52, 53], the investigators compared tweeted articles to non-tweeted articles for their citation output at 1-year follow-up. When compared to control articles, tweeted articles achieved significantly higher Altmetric scores, with more citations at 1 year, highlighting the durable scholarly impact of social media activity [2]. Multivariable analysis showed that independent predictors of citations were randomization to tweeting, higher Altmetric score, open-access status, and exposure to a larger number of Twitter followers as quantified by impressions [51]. This is consistent with previous social media research [52].

Based on data from subspecialty surgery, as mentioned above for thoracic surgery [51] and also for vascular surgery [54], there seems to be positive correlation for some papers with higher citations after social media exposure. However, such correlation was not found in two studies on plastic and aesthetic surgery papers $[48,70]$ and only weak associations were found for Covid-19 papers [55]. Hence, it remains to be shown if these alternative metrics related to tweets, mentions in blogs, displays in news outlets, etc. will have any impact on the majority of research being published in surgical journals.

\section{Some concerns of SoMe}

Social media is an unedited, live, non-curated, short textbased forum where statements, claims, and voices may go unchecked yet widely distributed. There is a risk for false 


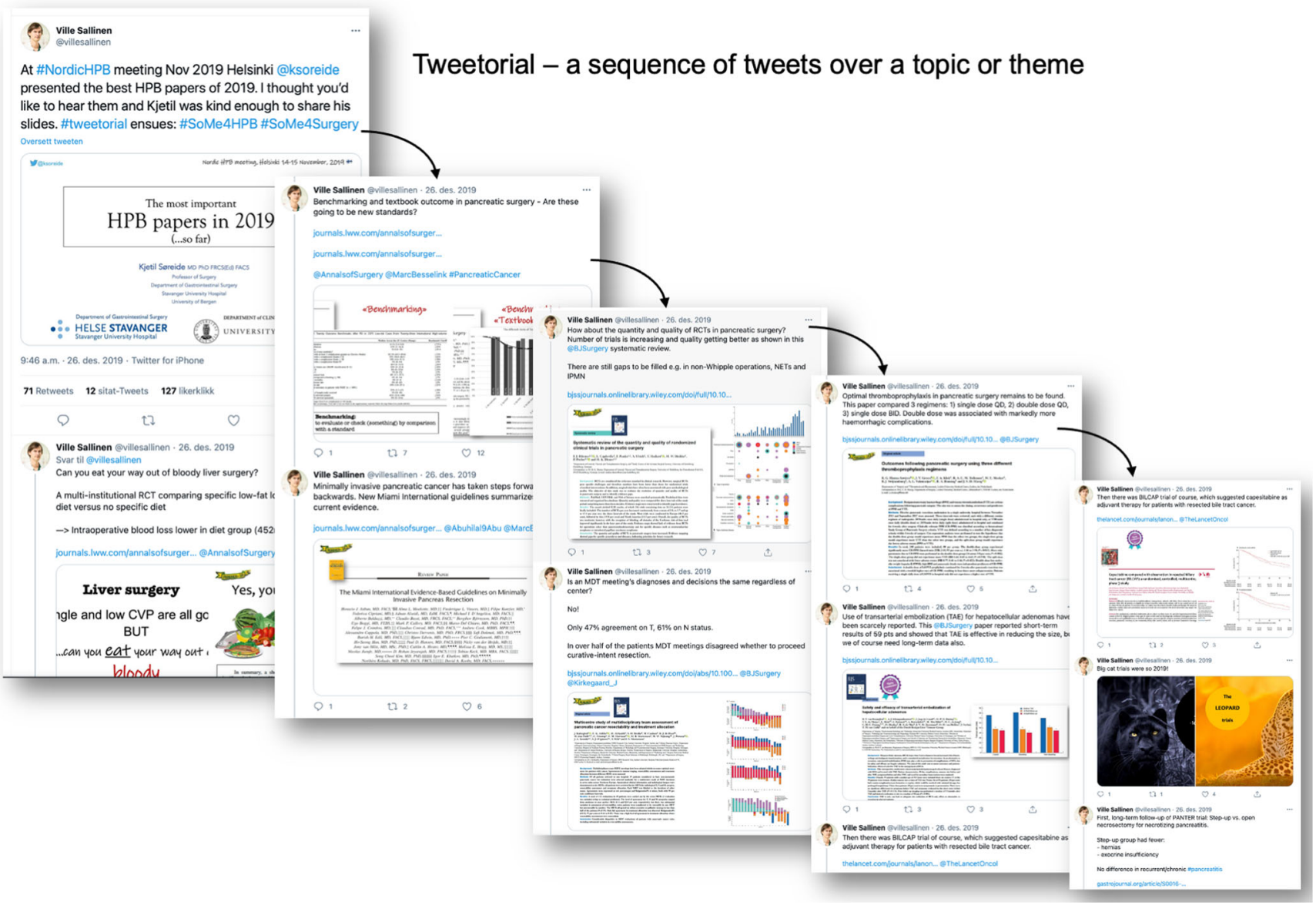

Fig. 3 Example of a tweetorial. After the 2019 Nordic HPB meeting in Helsinki, Finland, a tweetorial was presented by the host Ville Sallinen of a summary presentation. The full tweetorial can be read at https://twitter.

claims and so-called fake news [56] to appear-even in the scientific literature. Followers, readers, and participants need to keep a critical mind when reading and retweeting contentthis has become even more prudent and scrutinized after the 2020 US presidential election, with impact of social media usage beyond political campaigns.

Creation of echo chambers is a real risk with SoMe, with a huge number of followers applauding a statement or claim, while shooting down any counterarguments (real or not). Sound debates really are fruitful, but "trolling" and "bullying" are threats to the sound debates in several instances.

There is a risk for influencers being heard and having a voice based on a strong presence and wide activity on social media, rather than being true experts or contributors to the scientific field or community per se. The discrepancy between the SoMe presence and the actual contribution to the field has been dubbed the "Kardashian index" by Hall [57] — simply "being famous for being famous," without really having contributed. Identification of "influencers and Twitter stars" may be largely variable between specialties and countries $[58,59$, $81,82]$. Few investigations exist into the matter, but some studies $[82,83]$ from the field of cardiology found that expert com/villesallinen/status/1210119626165755905. The use of social media allows non-participants to take part and engage in content, allowing for a wider distribution and input to a meeting

scientists have significantly more relevant audiences than socalled twitteratis (i.e., persons being influential through very high activity on Twitter) while the need for active participation and implication from the forefront of academia is still high. In addition, as long as true equity in academia remains a utopian dream, having a high Kardashian index may not be a bad thing, if it allows the playing field to be leveled; having fewer publications and citations does not make one's opinions less valid, nor their contributions less valuable. As in any field of debate, it is crucial to separate actual information from mere noise.

Language and participation restrictions should also be noted. SoMe activity and use of various platforms are widely variable across the world. This can lead to the point of geographic exclusion as some regions are not participating or largely underrepresented in debates or discussions that become "truth" or "representative" of an opinion. Also, the use of professional and private use is very different between professionals [84], with some mixing both, others strictly professional and some merely for fun or social networking. However, the balance can be difficult and intriguing, particularly when considering conduct deemed unprofessional. 
a

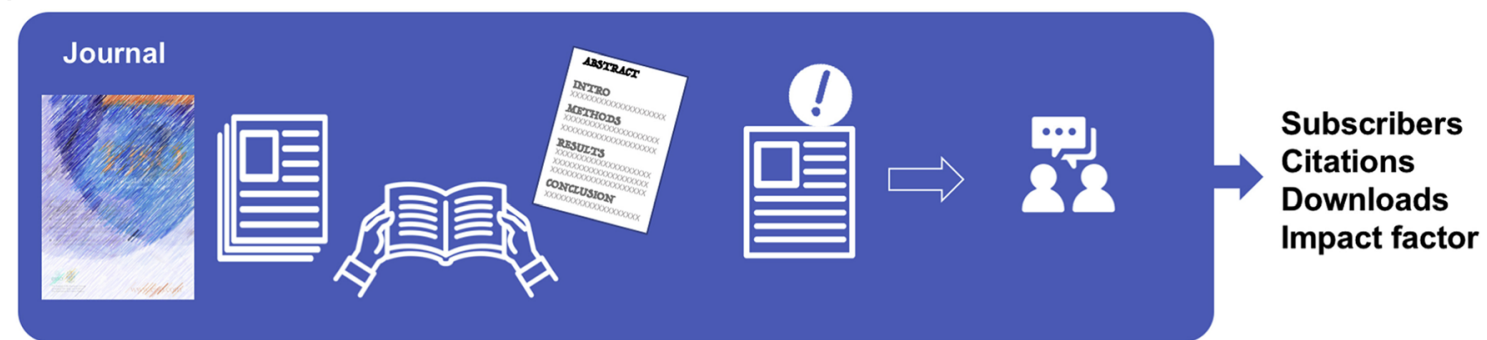

b

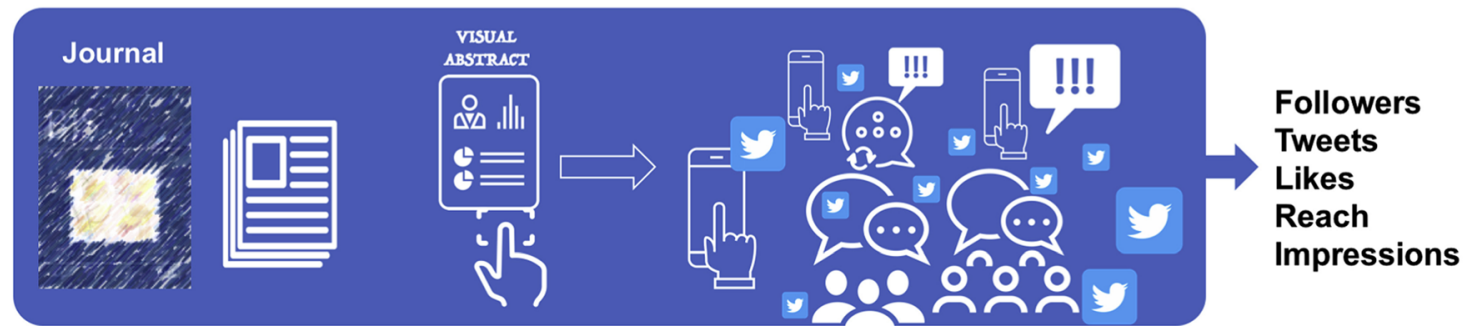

Fig. 4 Traditional and alternative metrics for measuring research output. The metrics used to evaluate the impact of social media activity are changing; in a, the traditional focus on citations and impact factor (IF; Journal Citation Reports (C) Clarivate Analytics) is increasingly challenged by b alternative metrics, dubbed "altmetrics" for short (collected by various projects, including Altmetric, Plum Analytics, and ImpactStory), that collect views and mentions over a wide range of

Notably, a study published in J Vasc Surgery aimed to look into the matter of "unprofessional behavior" by fellow trainee colleagues [85], only to later be retracted from the same journal $[86,87]$. The reason for the retraction was among others the inappropriate categorization of other persons' behavior based on simple views on the said persons' social media profile (e.g., a photo with a drink in hand; from a beach during vacation, or similar). This also created a response in the journal about who is to judge what is right and wrong [88], as well as a considerable "twitterstorm" (link here: https://twitter. com/JVascSurg/status/1286831352520888320). Indeed, the debate even led to the \#MedBikini hashtag used by women sources, including (but not limited to) peer reviews on faculty of 1000 , citations on Wikipedia and in public policy documents, discussions on research blogs, mainstream media coverage, bookmarks on reference managers like Mendeley, and social networks such as Twitter. Reproduced with permission from Elsevier under the Creative Commons license from Søreide [3]

doctors and allies globally that were offended by what male colleagues would deem inappropriate or unprofessional attire. Again, this has testified to the important role of SoMe to focus on diversity, gender equity, breaking down biases and stereotypes, and leveling out the playing field — with immediate action taken by journal editors [89].

Hence, several factors need to be kept in mind when interpreting the role and importance of debates and the content a hand. Suggestions to appropriate debate and collegial behavior for SoMe are available and published by societies or specialist journals [19, 90-95] and, importantly also, by most institutions these days. The most overarching point for
Table 5 Standard or essential information to include in a visual abstract

\begin{tabular}{ll}
\hline Guideline & Rationale \\
\hline State the question or purpose of study & Place the study in context \\
Describe research design & Make quality of evidence clear \\
Report primary outcome & Reduce reporting bias \\
Report $p$-value or outcome measure & Allow reader interpretation \\
Label citation of the article and provide full URL & Facilitate easy access to main source; contribute to \\
$\quad$ link to article & Altmetric score \\
Use same language as in article & Consistency, reduce bias \\
Use images with permissions to reuse & $\begin{array}{l}\text { Prevent violation of copyrights } \\
\text { External review (by someone unfamiliar with the }\end{array}$ \\
$\quad$ Obtain feedback on readability, ensure credibility, and \\
Post on social media platforms & identify bias \\
\hline
\end{tabular}

Modified and developed from Ibrahim [39] 


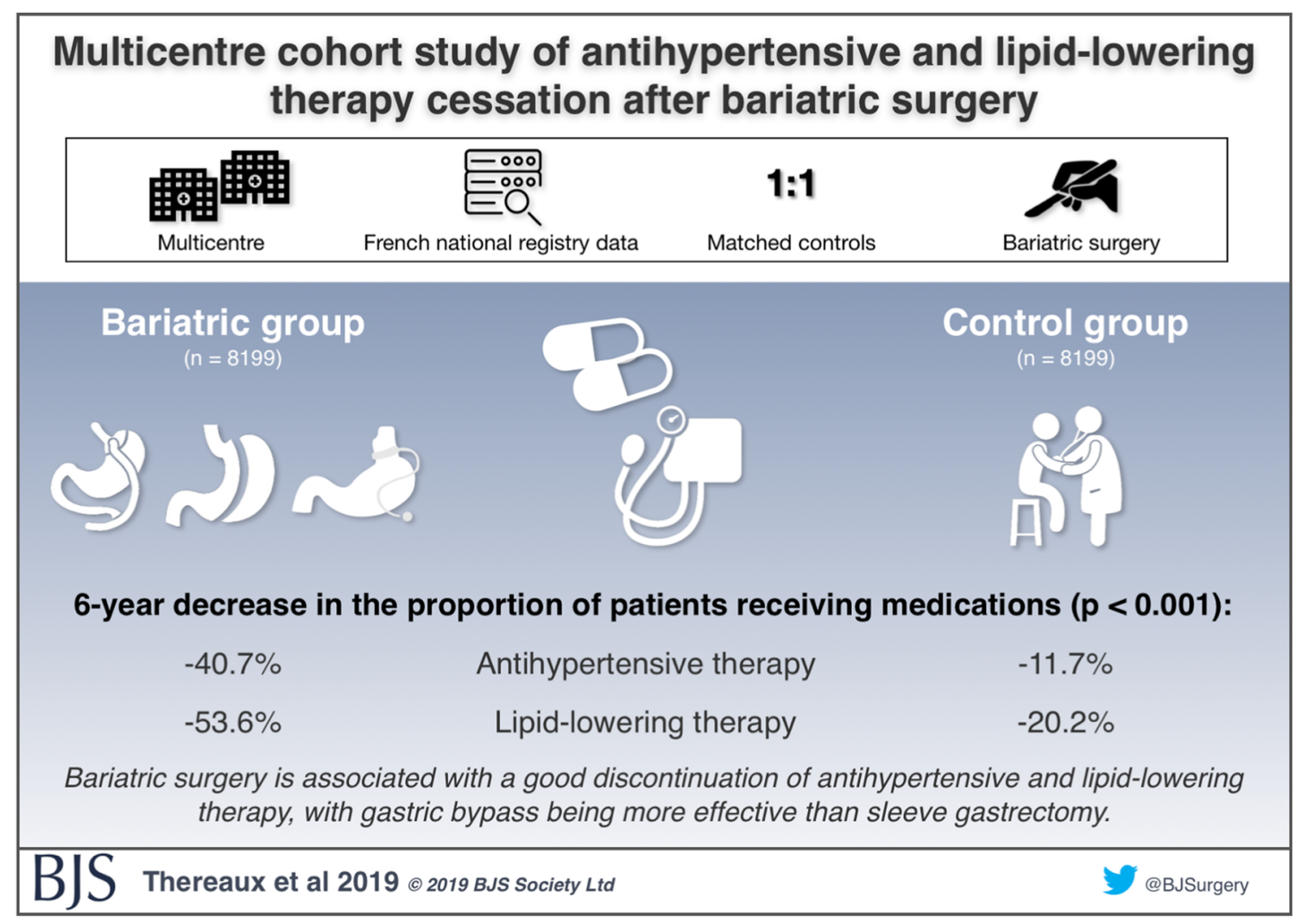

Fig. 5 The visual abstract. An example of a visual abstract used to post summary content of a study published in $B J S$ (courtesy of R. G.). The tweet with the visual abstract also contains a few notes on the study and should also contain a link or shortcut to the paper itself, hence acting as a teaser to attract the reader to study the full-text version. Thus, the purpose of the visual abstract is to be simplistic in message, yet will not replace the need to read and understand the full depth of the paper
Table 6 Examples of Twitter accounts that curate surgical content

\begin{tabular}{|c|c|c|c|}
\hline Twitter name & Twitter handle & Description & Joined \\
\hline Transplant Library & @ Transplant_TL & $\begin{array}{l}\text { Transplant Library: the world's most used } \\
\text { online information resource for transplant } \\
\text { professionals. One Place, All Evidence! }\end{array}$ & March 2013 \\
\hline Surgical Research & @ SurgeryScience & $\begin{array}{l}\text { Latest surgical research journal papers as } \\
\text { they're published | Academic updates and } \\
\text { CME | @ DrEdFitzgerald }\end{array}$ & $\begin{array}{r}\text { August } \\
2014\end{array}$ \\
\hline Colorectalsurgery & @ colorectaltweet & $\begin{array}{l}\text { Developments and Research in coloproctology } \\
\text { - harvests the best tweets from research on } \\
\text { \#colorectalsurgery hashtag and from the } \\
\text { colorectal twitterazzi }\end{array}$ & May 2016 \\
\hline \#ColorectalResearch & @ colo_research & $\begin{array}{l}\text { A virtual journal of the best research from } \\
\text { \#colorectalresearch - jointly authored from } \\
\text { @ bjsurgery @ colorectaldis } \\
\text { @ techcoloproctol @ dcrjournal }\end{array}$ & July 2017 \\
\hline Surgery Highlights & @ SurgeryGo & $\begin{array}{l}\text { For \#Surgeons around [globe emoji] to stay } \\
\text { engaged with \#Basic \& \#Clinical \#Surgery, } \\
\text { \#Surgical \#Innovation \& \#Research. } \\
\text { originals in Favorites }\end{array}$ & July 2017 \\
\hline Roux Library & @UpperGIResearch & $\begin{array}{l}\text { Virtual Twitter library curating the latest upper } \\
\text { gastrointestinal surgery research. } \\
\text { \#UpperGIResearch \#HPB \#Bariatrics \#OG } \\
\text { \#FOAMed \#EBM \#SurgicalResearch }\end{array}$ & July 2017 \\
\hline
\end{tabular}




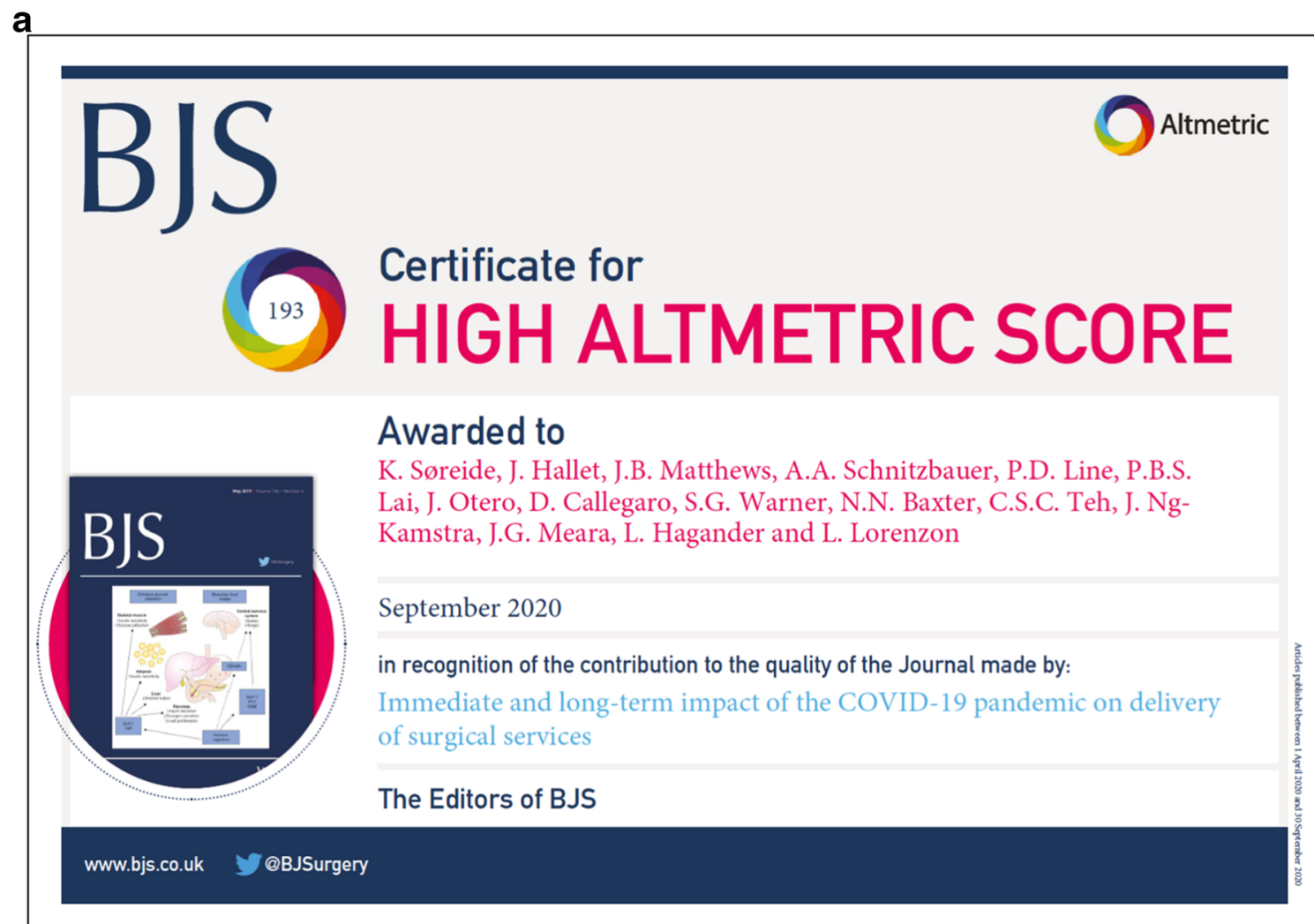

b

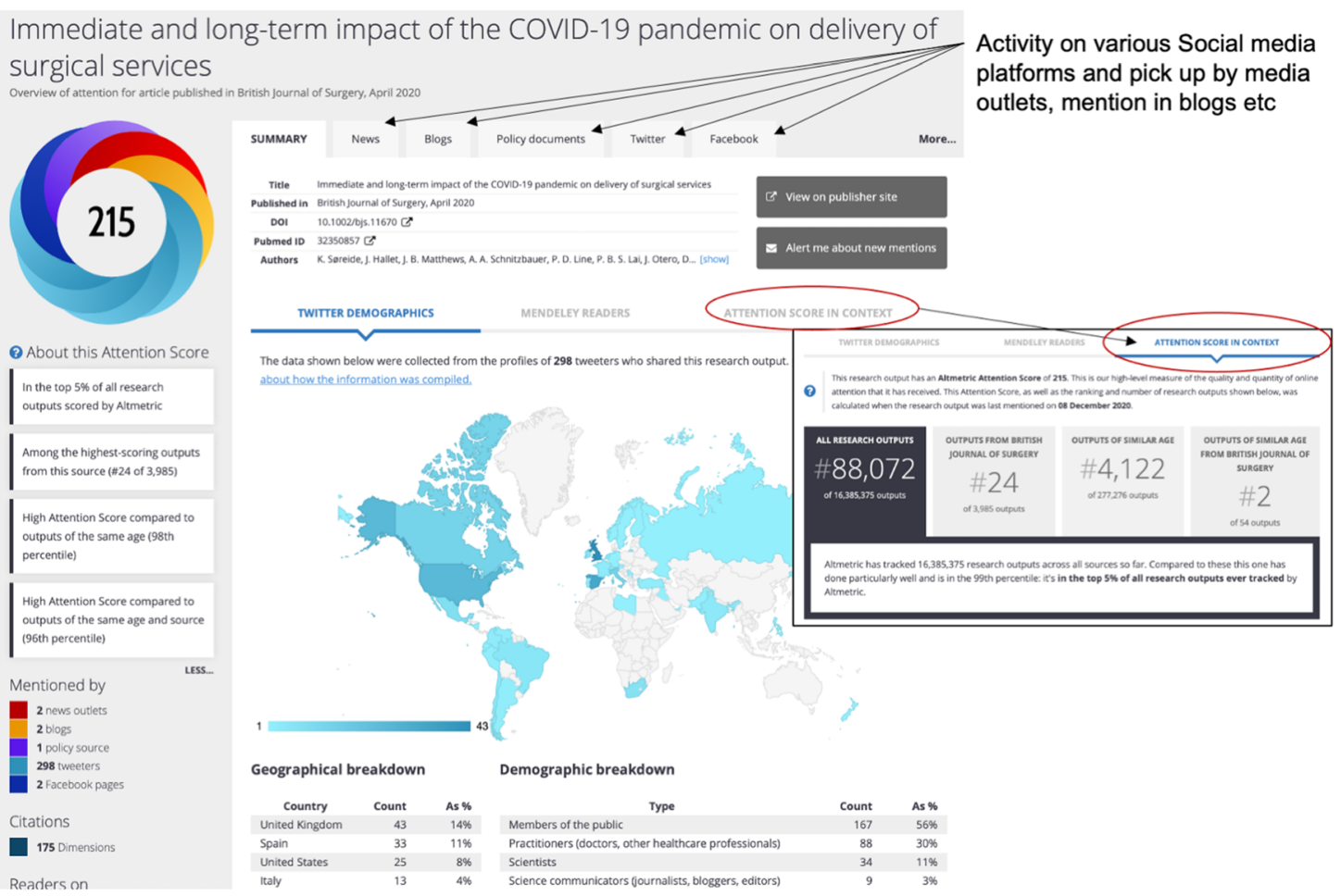

[up to December $13^{\text {th }}, 2020$ ]

Fig. 6 An example of an Altmetric certificate. Some journals are now providing certificate to high Altmetric scoring papers, as shown in an example (a). The Altmetric score captures activity on social media platforms and news outlets, and gives an impression of immediate attention and global reach (b) but it is unclear to what degree this returns on citations or actual impact 
surgeons and medical professional alike is nonetheless to maintain patient confidentiality and dignity at all times.

Patients may engage with surgeons on SoMe, which can be good thing; patients or their next of kin may learn about conditions in plain English (or the language in question at the platform), it may encourage public engagement, and doctors may get a perspective from the patient on priorities, wishes, thoughts, and needs. However, such contact can also potentially be concerning when crossing boundaries or conducted in an unprofessional manner. Some subspecialties may in particular have a fine line between providing information and bordering on actual advertisements for services [96-99].

Notably, technical issues should not be forgotten. A Twitter handle or social media account may be hacked or security breached. This should be considered both for the individual person but also if unusual or largely unexpected information is distributed from an account with unclear or largely deviating information.

\section{Conclusions}

Social media and their platforms have become yet another tool in the surgeon's armamentarium for communication and dissemination of research, and for interacting with colleagues and the public. As such, SoMe platforms and several communities have become effective for sharing knowledge and opinions. Some caveats and pitfalls need to be considered and more research is needed into the real-world impact of these platforms. However, the sound use of this dissemination technology has allowed cutting-edge research to reach a wider audience with a lower threshold for discussing new information. Hence, we believe these channels will continue to shape surgeons' way of obtaining new information, sharing new data, and engaging in scientific debates in the near future.

Funding Open access funding provided by University of Bergen (incl Haukeland University Hospital).

Data availability Not applicable.

Code availability Not applicable.

\section{Declarations}

Ethics approval Not applicable.

Conflict of interest The authors declare no competing interests.

Open Access This article is licensed under a Creative Commons Attribution 4.0 International License, which permits use, sharing, adaptation, distribution and reproduction in any medium or format, as long as you give appropriate credit to the original author(s) and the source, provide a link to the Creative Commons licence, and indicate if changes were made. The images or other third party material in this article are included in the article's Creative Commons licence, unless indicated otherwise in a credit line to the material. If material is not included in the article's Creative Commons licence and your intended use is not permitted by statutory regulation or exceeds the permitted use, you will need to obtain permission directly from the copyright holder. To view a copy of this licence, visit http://creativecommons.org/licenses/by/4.0/.

\section{References}

1. Ioannidis A, Blanco-Colino R, Chand M, Pellino G, Nepogodiev $\mathrm{D}$, Wexner SD, Mayol J (2020) How to make an impact in surgical research: a consensus summary from the \#SoMe4Surgery community. Updat Surg 72:1229-1235. https://doi.org/10.1007/s13304020-00780-z

2. Han JJ (2020) To tweet or not to tweet: no longer the question. Ann Thorac Surg 111:300-301. https://doi.org/10.1016/j.athoracsur. 2020.04.070

3. Søreide K (2019) Numbers needed to tweet: social media and impact on surgery. Eur J Surg Oncol 45(2):292-295. https://doi.org/ 10.1016/j.ejso.2018.10.054

4. Soragni A, Maitra A (2019) Of scientists and tweets. Nat Rev Cancer 19(9):479-480. https://doi.org/10.1038/s41568-019-01704

5. Devitt S, Kenkel JM (2020) Social media: a necessary evil? Aesthet Surg J 40(6):700-702. https://doi.org/10.1093/asj/sjz361

6. Mayol J, Dziakova J (2017) Value of social media in advancing surgical research. Br J Surg 104(13):1753-1755. https://doi.org/10. 1002/bjs. 10767

7. Maldonado AA, Lemelman BT, Le Hanneur M, Coelho R, Cristóbal L, Sader R et al (2020) Analysis of \#PlasticSurgery in Europe: an opportunity for education and leadership. Plast Reconstr Surg 145(2):576-584. https://doi.org/10.1097/prs. 0000000000006427

8. Asyyed Z, McGuire C, Samargandi O, Al-Youha S, Williams JG (2019) The use of Twitter by plastic surgery journals. Plast Reconstr Surg 143(5):1092e-1098e. https://doi.org/10.1097/prs. 0000000000005535

9. Brady RRW, Chapman SJ, Atallah S, Chand M, Mayol J, Lacy AM, Wexner SD (2017) \#colorectalsurgery. Br J Surg 104(11): 1470-1476. https://doi.org/10.1002/bjs.10615

10. BMJ T (2021) History of the BMJ. BMJ. https://www.bmj.com/ about-bmj/history-of-the-bmj. Accessed 7.2.2021.

11. Wikipedia (2021) Blog. https://en.wikipedia.org/wiki/Blog. Accessed 7.2.2021.

12. Wikipedia (2021) Podcast. Wikipedia. https://en.wikipedia.org/ wiki/Podcast. Accessed 7.2.2021.

13. Campbell L, Evans Y, Pumper M, Moreno MA (2016) Social media use by physicians: a qualitative study of the new frontier of medicine. BMC Med Inform Decis Mak 16:91. https://doi.org/10. 1186/s12911-016-0327-y

14. Long LE, Leung C, Hong JS, Wright C, Young CJ (2019) Patterns of internet and social media use in colorectal surgery. BMC Surg 19(1):52. https://doi.org/10.1186/s12893-019-0518-4

15. Perrin A, Anderson M. Share of U.S. adults using social media, including Facebook, is mostly unchanged since 2018. Pew Research Center, Pew Research Center. 2019. https://www. pewresearch.org/fact-tank/2019/04/10/share-of-u-s-adults-usingsocial-media-including-facebook-is-mostly-unchanged-since2018/. Accessed 7.2.2021.

16. Mackenzie G, Grossman R, Mayol J (2020) Beyond the hashtag: describing and understanding the full impact of the \#BJSConnect 
tweet chat May 2019. BJS Open. https://doi.org/10.1093/bjsopen/ zraa019.

17. Zerrweck C, Arana S, Calleja C, Rodríguez N, Moreno E, Pantoja JP, Donatini G (2020) Social media, advertising, and internet use among general and bariatric surgeons. Surg Endosc 34(4):1634 1640. https://doi.org/10.1007/s00464-019-06933-5

18. Cabrera LF, Ferrada P, Mayol J, Mendoza AC, Herrera G, Pedraza M, Sanchez S (2020) Impact of social media on the continuous education of the general surgeon, a new experience, @ Cirbosque: a Latin American example. Surgery. 167(6):890-894. https://doi. org/10.1016/j.surg.2020.03.008

19. Bittner JG, Logghe HJ, Kane ED, Goldberg RF, Alseidi A, Aggarwal R et al (2019) A Society of Gastrointestinal and Endoscopic Surgeons (SAGES) statement on closed social media (Facebook®) groups for clinical education and consultation: issues of informed consent, patient privacy, and surgeon protection. Surg Endosc 33(1):1-7. https://doi.org/10.1007/s00464-018-6569-2

20. Montemurro P, Cheema M, Tamburino S, Hedén P (2019) Online and social media footprint of all Swedish aesthetic plastic surgeons. Aesthet Plast Surg 43(5):1400-1405. https://doi.org/10.1007/ s00266-019-01392-8

21. Janik PE, Charytonowicz M, Szczyt M, Miszczyk J (2019) Internet and social media as a source of information about plastic surgery: comparison between public and private sector, A 2-center study. Plast Reconstr Surg Glob Open 7(3):e2127. https://doi.org/10. 1097/gox.0000000000002127

22. Ibrahim A, Abubakar LM, Maina DJ, Adebayo WO, Kabir AM, Asuku ME (2020) The millennial generation plastic surgery trainees in sub-Saharan Africa and social media: a review of the application of blogs, podcasts, and twitter as web-based learning tools. Ann Afr Med 19(2):75-79. https://doi.org/10.4103/aam. aam_25_17

23. Zhao JY, Romero Arenas MA (2019) The surgical blog: an important supplement to traditional scientific literature. Am J Surg 218(4):792-797. https://doi.org/10.1016/j.amjsurg.2019.07.028

24. GastricCancerAssociation C (2021) News Archive. Gastriccancer.ca. http://gastriccancer.ca/newsletterarchive/.

25. Shippee ND, Domecq Garces JP, Prutsky Lopez GJ, Wang Z, Elraiyah TA, Nabhan M, Brito JP, Boehmer K, Hasan R, Firwana B, Erwin PJ, Montori VM, Murad MH (2015) Patient and service user engagement in research: a systematic review and synthesized framework. Health Expect 18(5):1151-1166. https://doi.org/10. 1111/hex.12090

26. Celentano V, Smart N, Cahill RA, McGrath JS, Gupta S, Griffith JP et al (2019) Use of laparoscopic videos amongst surgical trainees in the United Kingdom. Surgeon 17(6):334-339. https://doi.org/10. 1016/j.surge.2018.10.004

27. Jyot A, Baloul MS, Finnesgard EJ, Allen SJ, Naik ND, Gomez Ibarra MA, Abbott EF, Gas B, Cardenas-Lara FJ, Zeb MH, Cadeliña R, Farley DR (2018) Surgery website as a 24/7 adjunct to a surgical curriculum. J Surg Educ 75(3):811-819. https://doi. org/10.1016/j.jsurg.2017.09.019

28. Clarke Hillyer G, Basch CH, Guerro S, Sackstein P, Basch CE (2019) YouTube videos as a source of information about mastectomy. Breast J 25(2):349-350. https://doi.org/10.1111/tbj.13222

29. Ferhatoglu MF, Kartal A, Filiz A, Kebudi A (2019) Comparison of new era's education platforms, YouTube ${ }^{\circledR}$ and WebSurg ${ }^{\circledR}$, in sleeve gastrectomy. Obes Surg 29(11):3472-3477. https://doi.org/ 10.1007/s11695-019-04008-x

30. Almarghoub MA, Alghareeb MA, Alhammad AK, Alotaibi HF, Kattan AE (2020) Plastic surgery on YouTube. Plast Reconstr Surg Glob Open 8(1):e2586. https://doi.org/10.1097/gox. 0000000000002586

31. Sturiale A, Dowais R, Porzio FC, Brusciano L, Gallo G, Morganti R, Naldini G (2020) YouTube as a source of patients and specialists' information on hemorrhoids and hemorrhoid surgery. Rev
Recent Clin Trials 15:219-226. https://doi.org/10.2174/ 1574887115666200525001619

32. Ferhatoglu MF, Kartal A, Ekici U, Gurkan A (2019) Evaluation of the reliability, utility, and quality of the information in sleeve gastrectomy videos shared on open access video sharing platform YouTube. Obes Surg 29(5):1477-1484. https://doi.org/10.1007/ s11695-019-03738-2

33. Keskinkılıç Yağız B, Yalaza M, Sapmaz A (2020) Is Youtube a potential training source for total extraperitoneal laparoscopic inguinal hernia repair? Surg Endosc. https://doi.org/10.1007/s00464020-07596-3

34. de Angelis N, Gavriilidis P, Martínez-Pérez A, Genova P, Notarnicola M, Reitano E et al (2019) Educational value of surgical videos on YouTube: quality assessment of laparoscopic appendectomy videos by senior surgeons vs. novice trainees. World J Emerg Surg 14:22. https://doi.org/10.1186/s13017-019-0241-6

35. Frongia G, Mehrabi A, Fonouni H, Rennert H, Golriz M, Günther $P$ (2016) YouTube as a potential training resource for laparoscopic fundoplication. J Surg Educ. 73(6):1066-1071. https://doi.org/10. 1016/j.jsurg.2016.04.025

36. Dixon M, Palter V, Brar S, Coburn N (2021) Evaluating quality and completeness of gastrectomy for gastric cancer: review of surgical videos from the public domain. Transl Gastro Hepatol.

37. Laurentino Lima D, RNCL L, Benevenuto D, Soares Raymundo T, Shadduck PP, Melo Bianchi J et al (2020) Survey of social media use for surgical education during Covid-19. JSLS 24(4): e2020.00072. https://doi.org/10.4293/jsls.2020.00072

38. Chang H-C (2010) A new perspective on Twitter hashtag use: diffusion of innovation theory. Proc Am Soc Inf Sci Technol 47(1):14. https://doi.org/10.1002/meet.14504701295

39. Grossman RC, Mackenzie DG, Keller DS, Dames N, Grewal P, Maldonado AA, Ioannidis A, AlHasan A, Søreide K, Teoh JYC, Wexner SD, Mayol J (2020) \#SoMe4Surgery: from inception to impact. BMJ Innovations 6(2):72-82. https://doi.org/10.1136/ bmjinnov-2019-000356

40. Morello L (2015) Science and sexism: in the eye of the twitterstorm. Nature. 527(7577):148-151. https://doi.org/10.1038/527148a

41. Ansari H, Pitt SC (2020) \#ILookLikeASurgeon: or do I? The local and global impact of a hashtag. Am J Surg. 10.1016/ j.amjsurg.2020.10.020.

42. Loeb S, Byrne NK, Thakker S, Walter D, Katz MS (2020) \#ILookLikeAUrologist: using Twitter to discuss diversity and inclusion in urology. Eur Urol Focus. 10.1016/j.euf.2020.03.005.

43. Do A-M (2014) The real reason why Facebook dominates Vietnam but Twitter could never make it. TechInAsia, TechInAsia. https:// www.techinasia.com/vietnam-loves-facebook-not-twitter. Accessed 7.2.2021.

44. Coca N (2018) Why Japan loves Twitter more than Facebook. OZY, OZY. https://www.ozy.com/around-the-world/why-japanloves-twitter-more-than-facebook/86545/. Accessed 7.2.2021.

45. Kalev L, Shaowen W, Guofeng C, Anand P, Eric S (2013) Mapping the global Twitter heartbeat: the geography of Twitter. First Monday 18(5). https://doi.org/10.5210/fm.v18i5.4366

46. Maggio LA, Meyer HS, Artino AR Jr (2017) Beyond citation rates: a real-time impact analysis of health professions education research using altmetrics. Acad Med 92(10):1449-1455. https://doi.org/10. 1097/acm.0000000000001897

47. Grant MC, Scott-Bridge KR, Wade RG (2020) The role of social media in disseminating plastic surgery research: the relationship between citations, altmetrics and article characteristics. J Plast Reconstr Aesthet Surg. https://doi.org/10.1016/j.bjps.2020.10.103

48. Boyd CJ, Ananthasekar S, Kurapati S, King TW (2020) Examining the correlation between altmetric score and citations in the plastic surgery literature. Plast Reconstr Surg 146(6):808e-815e. https:// doi.org/10.1097/prs.0000000000007378 
49. Richardson MA, Bernstein DN, Mesfin A (2020) Manuscript characteristics associated with the altmetrics score and social media presence: an analysis of seven spine journals. Spine J. https://doi. org $/ 10.1016 / j$.spinee.2020.11.001

50. Coret M, Rok M, Newman J, Deonarain D, Agzarian J, Finley C, Shargall Y, Malik PRA, Patel Y, Hanna WC (2019) Twitter activity is associated with a higher research citation index for academic thoracic surgeons. Ann Thorac Surg 110:660-663. https://doi.org/ 10.1016/j.athoracsur.2019.09.075

51. Luc JGY, Archer MA, Arora RC, Bender EM, Blitz A, Cooke DT, Hlci TN, Kidane B, Ouzounian M, Varghese TK Jr, Antonoff MB (2020) Does tweeting improve citations? One-year results from the TSSMN prospective randomized trial. Ann Thorac Surg 111:296300. https://doi.org/10.1016/j.athoracsur.2020.04.065

52. Luc JGY, Archer MA, Arora RC, Bender EM, Blitz A, Cooke DT, Hlci TN, Kidane B, Ouzounian M, Varghese TK Jr, Antonoff MB (2020) Social media improves cardiothoracic surgery literature dissemination: results of a randomized trial. Ann Thorac Surg 109(2): 589-595. https://doi.org/10.1016/j.athoracsur.2019.06.062

53. Ni hIci T, Archer M, Harrington C, JGY L, Antonoff MB (2020) Trainee thoracic surgery social media network: early experience with TweetChat-based journal clubs. Ann Thorac Surg 109(1): 285-290. https://doi.org/10.1016/j.athoracsur.2019.05.083

54. Chau M, Ramedani S, King T, Aziz F (2020) Presence of social media mentions for vascular surgery publications is associated with an increased number of literature citations. J Vasc Surg. https://doi. org/10.1016/j.jvs.2020.09.029.

55. Tornberg HN, Moezinia C, Wei C, Bernstein SA, Wei C, Al-Beyati $\mathrm{R}$ et al (2021) Assessing the dissemination of COVID-19 articles across social media with Altmetric and PlumX metrics: correlational study. J Med Internet Res 23(1):e21408. https://doi.org/10.2196/ 21408

56. Gilligan JT, Gologorsky Y (2019) \#Fake News: scientific research in the age of misinformation. World Neurosurg 131:284. https://doi. org/10.1016/j.wneu.2019.08.083

57. Hall N (2014) The Kardashian index: a measure of discrepant social media profile for scientists. Genome Biol 15(7):424. https://doi.org/ 10.1186/s13059-014-0424-0

58. Elson NC, Le DT, Johnson MD, Reyna C, Shaughnessy EA, Goodman MD et al. (2020) Characteristics of general surgery social media influencers on Twitter. Am Surg :3134820951427. https:// doi.org/10.1177/0003134820951427.

59. Varady NH, Chandawarkar AA, Kernkamp WA, Gans I (2019) Who should you be following? The top 100 social media influencers in orthopaedic surgery. World J Orthop 10(9):327338. https://doi.org/10.5312/wjo.v10.i9.327

60. Breu AC (2020) From tweetstorm to tweetorials: threaded tweets as a tool for medical education and knowledge dissemination. Semin Nephrol 40(3):273-278. https://doi.org/10.1016/j.semnephrol. 2020.04.005

61. Heßler N, Rottmann M, Ziegler A (2020) Empirical analysis of the text structure of original research articles in medical journals. PLoS One 15(10):e0240288. https://doi.org/10.1371/journal.pone. 0240288

62. Ibrahim AM, Lillemoe KD, Klingensmith ME, Dimick JB (2017) Visual abstracts to disseminate research on social media: a prospective, case-control crossover study. Ann Surg 266(6):e46-ee8. https://doi.org/10.1097/sla.0000000000002277

63. Chapman SJ, Grossman RC, FitzPatrick MEB, Brady RRW (2019) Randomized controlled trial of plain English and visual abstracts for disseminating surgical research via social media. Br J Surg 106: 1611-1616. https://doi.org/10.1002/bjs.11307

64. Ramos E, Concepcion BP (2020) Visual abstracts: redesigning the landscape of research dissemination. Semin Nephrol 40(3):291297. https://doi.org/10.1016/j.semnephrol.2020.04.008
65. Ibrahim AM (2018) Seeing is believing: using visual abstracts to disseminate scientific research. Am J Gastroenterol 113(4):459 461. https://doi.org/10.1038/ajg.2017.268

66. Buckarma EH, Thiels CA, Gas BL, Cabrera D, Bingener-Casey J, Farley DR (2017) Influence of social media on the dissemination of a traditional surgical research article. J Surg Educ. 74(1):79-83. https://doi.org/10.1016/j.jsurg.2016.06.019

67. Nikolian VC, Ibrahim AM (2017) What does the future hold for scientific journals? Visual abstracts and other tools for communicating research. Clin Colon Rectal Surg 30(4):252-258. https://doi. org/10.1055/s-0037-1604253

68. Johannsson H, Selak T (2020) Dissemination of medical publications on social media - is it the new standard? Anaesthesia. 75(2): 155-157. https://doi.org/10.1111/anae.14780

69. Sathianathen NJ, Lane R 3rd, Condon B, Murphy DG, Lawrentschuk N, Weight CJ, Lamb AD (2020) Early online attention can predict citation counts for urological publications: the \#UroSoMe_Score. Eur Urol Focus 6(3):458-462. https://doi.org/ 10.1016/j.euf.2019.10.015

70. Asaad M, Howell SM, Rajesh A, Meaike J, Tran NV (2020) Altmetrics in plastic surgery journals: does it correlate with citation count? Aesthet Surg J 40:NP628-NP635. https://doi.org/10.1093/ asj/sjaa158

71. Kunze KN, Polce EM, Vadhera A, Williams BT, Nwachukwu BU, Nho SJ, Chahla J (2020) What is the predictive ability and academic impact of the altmetrics score and social media attention? Am J Sports Med 48(5):1056-1062. https://doi.org/10.1177/ 0363546520903703

72. Smith ZL, Chiang AL, Bowman D, Wallace MB (2019) Longitudinal relationship between social media activity and article citations in the journal Gastrointestinal Endoscopy. Gastrointest Endosc 90(1):77-83. https://doi.org/10.1016/j.gie.2019.03.028

73. Tonia T, Van Oyen H, Berger A, Schindler C, Künzli N (2020) If I tweet will you cite later? Follow-up on the effect of social media exposure on article downloads and citations. Int J Public Health 65(9):1797-1802. https://doi.org/10.1007/s00038-020-01519-8

74. Mullins CH, Boyd CJ, Corey BL (2020) Examining the correlation between altmetric score and citations in the general surgery literature. J Surg Res 248:159-164. https://doi.org/10.1016/j.jss.2019. 11.008

75. Grossman RC (2019) This month on Twitter. Br J Surg 106(7):814. https://doi.org/10.1002/bjs. 11255

76. Grossman R (2019) Tweets of the month—January. Br J Surg 106(3):297. https://doi.org/10.1002/bjs.11130

77. Grossman RC (2020) This month on Twitter. Br J Surg 107(13): 1855. https://doi.org/10.1002/bjs.12071

78. Grossman RC (2020) Tweets of the month. Br J Surg 107(1):155. https://doi.org/10.1002/bjs.11492

79. Aroeira RI (2020) M ARBC. Can citation metrics predict the true impact of scientific papers? FEBS J 287(12):2440-2448. https:// doi.org/10.1111/febs. 15255

80. Chapman CA, Bicca-Marques JC, Calvignac-Spencer S, Fan P, Fashing PJ, Gogarten J, Guo S, Hemingway CA, Leendertz F, Li B, Matsuda I, Hou R, Serio-Silva JC, Chr. Stenseth N (2019) Games academics play and their consequences: how authorship, h-index and journal impact factors are shaping the future of academia. Proc Biol Sci 286(1916):20192047. https://doi.org/10.1098/ rspb.2019.2047

81. You J (2014) Scientific community. Who are the science stars of Twitter? Science. 345(6203):1440-1441. https://doi.org/10.1126/ science.345.6203.1440

82. Khan MS, Shahadat A, Khan SU, Ahmed S, Doukky R, Michos ED, Kalra A (2020) The Kardashian index of cardiologists: celebrities or experts? JACC Case Rep 2(2):330-332. https://doi.org/10. 1016/j.jaccas.2019.11.068 
83. Pawar S, Siddiqui G, Desai NR, Ahmad T (2018) The Twittersphere Needs Academic Cardiologists!: \#heartdisease \#No1Killer \#beyondjournals. JACC Heart Fail 6(2):172-173. https://doi.org/10.1016/j.jchf.2017.10.008

84. Langenfeld SJ, Vargo DJ, Schenarts PJ (2016) Balancing privacy and professionalism: a survey of general surgery program directors on social media and surgical education. J Surg Educ 73(6):e28-e32. https://doi.org/10.1016/j.jsurg.2016.07.010

85. Hardouin S, Cheng TW, Mitchell EL, Raulli SJ, Jones DW, Siracuse JJ, Farber A (2019) Prevalence of unprofessional social media content among young vascular surgeons. J Vasc Surg 72: 667-671. https://doi.org/10.1016/j.jvs.2019.10.069

86. (2020) Retraction notice. J Vasc Surg 72(4):1514. https://doi.org/ 10.1016/j.jvs.2020.08.018.

87. Hardouin S, Cheng TW, Mitchell EL, Raulli SJ, Jones DW, Siracuse JJ, Farber A (2020) RETRACTED: prevalence of unprofessional social media content among young vascular surgeons. $\mathrm{J}$ Vasc Surg 72(2):667-671. https://doi.org/10.1016/j.jvs.2019.10. 069

88. Stamp N, Mitchell R, Fleming S (2020) Social media and professionalism among surgeons: who decides what's right and what's wrong? J Vasc Surg 72(5):1824-1826. https://doi.org/10.1016/j. jvs.2020.07.076

89. Sosa JA (2020) Editorial: doubling down on diversity in the wake of the \#MedBikini controversy. World J Surg 44(11):3587-3588. https://doi.org/10.1007/s00268-020-05751-4

90. Cho MJ, Furnas HJ, Rohrich RJ (2019) A primer on social media use by young plastic surgeons. Plast Reconstr Surg 143(5):15331539. https://doi.org/10.1097/prs.0000000000005533

91. Kung JW, Wigmore SJ (2020) How surgeons should behave on social media. Surgery (Oxf) 38(10):623-626. https://doi.org/10. 1016/j.mpsur.2020.07.014

92. Bernardi K, Shah P, Askenasy EP, Balentine C, Crabbe MM, Cerame MA et al (2020) Is the American College of Surgeons
Online Communities a safe and useful venue to ask for surgical advice? Surg Endosc 34(11):5041-5045. https://doi.org/10.1007/ s00464-019-07299-4

93. Bailey A (2019) Social media: the good, the bad, and the ugly. Plast Surg Nurs 39(3):66. https://doi.org/10.1097/psn. 0000000000000271

94. Chen AD, Furnas HJ, Lin SJ (2020) Tips and pearls on social media for the plastic surgeon. Plast Reconstr Surg 145(5):988e-996e. https://doi.org/10.1097/prs.0000000000006778

95. McNeely MM, Shuman AG, Vercler CJ (2020) Ethical use of public networks and social media in surgical innovation. J Laparoendosc Adv Surg Tech A. https://doi.org/10.1089/lap. 2019.0758

96. Atiyeh BS, Chahine F, Abou Ghanem O (2020) Social media and plastic surgery practice building: a thin line between efficient marketing, professionalism, and ethics. Aesthetic Plast Surg. https://doi. org/10.1007/s00266-020-01961-2.

97. Varghese TK Jr, Entwistle JW 3rd, Mayer JE, Moffatt-Bruce SD, Sade RM (2019) Ethical standards for cardiothoracic surgeons' participation in social media. J Thorac Cardiovasc Surg 158(4): 1139-1143. https://doi.org/10.1016/j.jtcvs.2019.03.029

98. Hetzler PT, Makar KG, Baker SB, Fan KL, Vercler CJ (2020) Time for a consensus? Considerations of ethical social media use by pediatric plastic surgeons. Plast Reconstr Surg 146(6):841e-842e. https://doi.org/10.1097/prs.0000000000007389

99. Schoenbrunner A, Gosman A, Bajaj AK (2019) Framework for the creation of ethical and professional social media content. Plast Reconstr Surg 144(1):118e-125e. https://doi.org/10.1097/prs. 0000000000005782

Publisher's note Springer Nature remains neutral with regard to jurisdictional claims in published maps and institutional affiliations. 